\title{
Burnout syndrome, working conditions, and health: a reality among public high school teachers in Brazil
}

\author{
Ângela Maria C. Santana*, Dione De Marchi, Luiz C. G. Junior, Yassana M. Girondoli, Andrés \\ Chiappeta \\ Nutrition and Health Department, Federal University of Viçosa - CEP: 36570-000 - Viçosa, MG - Brazil
}

\begin{abstract}
The objective of the study was to evaluate the occurrence of Burnout Syndrome in 100 teachers of six public high schools and its correlation with working conditions in a southeast city of Brazil. Characterization of the sample occurred after application of a socio-demographic questionnaire. Evaluation of the working conditions was done by means of an Ergonomic Working Analysis. The presence of Burnout Syndrome was evaluated by means of the Maslach Burnout Inventory. The sample presented the predominance of women, with an average age of 40.4 and the majority married with children. Roughly $50 \%$ had less than 10 years of service, and more than half of the teachers taught more than 18 classes per week. Hoarseness after work was principally reported among women, which required many days off for health treatment. Environmental conditions reflect inadequacy in relation to noise, light, humidity and temperature. Presence of pain in the upper limbs was especially high among women. Risk of musculoskeletal disorders in the upper limbs predominated as moderately important to significant. We also identified an average distance walked by teachers of $1.5 \mathrm{Km}$ and an average of $4.2 \mathrm{Kg}$ of school supplies carried between classes. The Burnout Syndrome presented a high score for depersonalization principally among men, but it has association with both sexes. Emotional exhaustion correlates with noise, depersonalization, and personal fulfillment, in addition to the high number of weekly lessons. It can be concluded that Burnout syndrome is present among teachers, principally in terms of depersonalization, deserving the attention of government officials and the schools, as well as the teachers themselves.
\end{abstract}

Keywords: Burnout syndrome, Working conditions, Teachers

\section{Introduction}

Teaching is no longer a rewarding profession, because in addition to the low salaries, its social value which followed this function some decades ago, was reduced [11].

The Institute for Statistics of United Nations Educational, Scientific and Cultural Organization (UISUNESCO) [39] by following the education situation, highlights a reduction of teacher/educators, emphasizing the importance of investments in education, and mainly in the education profession. It is estimated that until 2015, Brazil will have to hire 396,000 new teachers to guarantee universalization of basic education.
This panorama through which teachers have been passing over the years, has brought a series of healthrelated problems, including those related to mental health, in which Burnout syndrome is highlighted.

Burnout is a typical syndrome in the labor environment, a process which occurs in response to occupational stress becoming chronic, bringing with it negative consequences at the individual and professional level, as well as family and social levels [5].

Burnout syndrome differs from stress due to the involvement of negative attitudes and behaviors related to client users, to the organization and to the work in a general way [33].

Studies show the involvement of a considerable number of teachers whom suffer with this syndrome. * Corresponding author: Ângela Maria C. Santana. Nutrition and Health Department, Federal University of Viçosa, Viçosa, MG, Brazil.
CEP: 36570-000 - E-mail:santana@ufv.br - Phone Numbers: (31)38991267 or (31)99655173 
Gasparini et al. (2005) [15], working with elementary school teachers in Belo Horizonte, reported a prevalence of $50.3 \%$ mental disorders in this population, and Burnout was framed in this disorders.

Another study carried out by Codo et al. (1999) [11], investigating 5,200 subjects in 1,440 schools in Brazil for over 2.5 years, showed that $48.0 \%$ of education workers in Brazil suffer with some symptom of this disease, and among the teachers, $25.0 \%$ present with the complete picture of Burnout syndrome. Levy et al. (2008) [23], working with Rio de Janeiro city school teachers, found a prevalence of $70.13 \%$ in a sample of 54 teachers.

It is realized that Burnout syndrome presents a range of prevalence affecting different jobs: $63.3 \%$ among doctors, $35.7 \%$ among nurses; and among teachers: it can be found in the range from 25.0 to $70.13 \%$ [11-15-23].

Guglielmi et al. (1998) reported that Burnout syndrome was a significant social problem in many countries, implying organizational and personal costs.

As previously stated, Burnout is a syndrome caused by the environment and work conditions, and may lead the individual to a physical, emotional, and mental exhaustion caused by the involvement of the person in situations of high emotional demand for a long period of time. In the educational environment, it impairs education goals, resulting in alienation, cynicism among others, culminating in job abandonment.

The objective of this study was to evaluate the occurrence of Burnout syndrome in teachers at public schools in a southeastern city in Brazil and its correlation with work and health conditions.

\section{Methodology}

This work is a transversal, individual, exploratory study, carried out in six state schools in a city of southeastern Brazil.

The sample was composed of 100 teachers who agreed to take part in this study, most of them, $(65 \%)$ were women, at 22 to 64 years old and an average age of 40.4 years. Among men, age ranged from 21 to 61 years old, at an average age of 35.8 years.

\subsection{Evaluation of work conditions}

To evaluate working conditions of the teachers, Work Ergonomics Analysis (WEA) was used, according to Guérin et al. (2001) [18]. Thus, fixed situations of teaching activity were identified and re- corded from analysis of school rules obtained in each school.

Physical conditions of work environment were evaluated in the following aspects: (I) all desks, including those used by the teachers, were quantified and measured because teachers assist students individually, adopting some uncomfortable postures, not to mention the eye effort for reading students' books and notebooks; (II) blackboards were also measured for identification of effective working area of the teacher; (III) noise levels were evaluated by using DEC - 460 Sound Level Meter (Instrutherm); (IV) luminosity, temperature and air relative humidity were also evaluated by using a digital hygro-thermoanemometer light meter (model THAL-300, Instrutherm).

\subsection{Evaluation of pain complains}

To evaluate pain complaints after work shift, teachers were asked on the existence or nonexistence of pains and their respective sites already affected in a period previous to starting work as teachers. In addition, the body diagram was used Corlett \& Manenica (1980) [12], with a chart scale with five different pain intensities: no pain, light, moderate, intense, and maximum.

\subsection{Evaluation of arm height above head}

The height which each teacher reaches with the arm extended above their head, $180^{\circ}$ in relation to the trunk, was measured to identify vertical hand reaching during writing on the blackboard. Thus, a metal measuring tape was used (8-m STARRET, T1-8 model), to measure the vertical distance from the floor to teacher's hand reaching with arm extended at its maximum reach. The teacher remained with his back to the wall with his heels, back, and head leaning against the wall while measurement was taken from the point of the middle finger, which was marked with a pencil on the wall [1-28]. This measurement was compared to the average of blackboards found in classrooms and evaluated in this study, to check adequacy of the blackboards for the teachers.

\subsection{Evaluation of work-related risks for musculoskeletal disorders of upper limbs}

The evaluation of risks for musculoskeletal disorders of the upper limbs was carried out by applying a check-list called Simplified Evaluation of Biome- 
chanical Factor in Work-Related Upper limb Musculoskeletal disorders, proposed by Couto (2002) [13].

\subsection{Displacement evaluation}

A pedometer (Digi Walker, SW701 model) was used to measure the distance of how far teachers walk during a work shift.

\subsection{Evaluation of transported load during work shift}

A digital scale was placed in the teacher's room (Toledo, Junior model, $5 \mathrm{~g}$ sensitivity, minimal record of $100 \mathrm{~g}$ and maximum load of $15 \mathrm{~kg}$ ) to check the weight of the material transported by the teachers during the period they were at school, going from one classroom to the other, as well as the weight of the books they used.

\subsection{Evaluation of Burnout syndrome}

The presence of Burnout síndrome was evaluated by aplying Maslach Burnout Inventory [25] translated and validated into Portuguese by Tamayo (1997) [36].

\subsection{Statistical analysis}

Database and statistical analysis were built and performed by using softwares SPSS 17.0, MiniTab 14.0 and Excel 2007. The level of significance lower than $5 \%(\mathrm{p}<0.05)$ was used as basis for precision.

To evaluate normal distribution of selected variables in the statistical analysis of Burnout factors with other variables, the Kolmogorov-Smirnov test was carried out.

The Chi-square test was used among two elements of Burnout syndrome (Emotional burnout and depersonalization) for association with labor variables.

For correlation of environmental variables in relation to Burnout syndrome variables, a sample of 31 teachers was used in terms of the analysis made with those teachers who were focused on during the labor variables and answered the Burnout questionnaire.

For correlation among Burnout syndrome variables and demographic variables, a sample with 85 teachers was used, considering those who answered the social-demographic questionnaire and the Burnout questionnaire.

For quantitative evaluation of coefficients of correlation, the classification described by CallegariJacques was used (2003): null (0), weak $(0-0.3)$, regular $(0.3-0.6)$, strong $(0.6-0.9)$, very strong $(0.9$ $-1)$, complete or perfect (1).

\section{Results}

This study was composed of 100 teachers, most of them $(65 \%)$ were women, at 22 to 64 years old and average age of 40.4 years old. Among men, age ranged from 21 to 61 years old, with an average age of 35.8 years old. Noted that $51 \%$ of the teachers were married and $56 \%$ had children.

Most of the teachers were married (51\%), 36\% have been working as teachers for 1 to 5 years , $46 \%$ were completed graduated, and $55 \%$ were tenured and gave more than 18 classes weekly. Less than 5 years teaching and average age of 40.4 years old indicated that most teachers started to work as teachers after 30 years of age and they have less teaching experience. Concerning life style of the teachers, $12 \%$ were smokers and 57\% drank alcoholic beverages and $49 \%$ practiced physical activities regularly.

\subsection{Working conditions}

To follow up the teachers' work, a periodical evaluation was carried out, in which professional development, interpersonal relationship and techinicalprofesional abilities were evaluated.

High-school classes presented an average of 34 students. Teachers had a high hours-load, with 18 hours or more, they usually taught five classes in a row, with a real break only in the interval or in the transition period from one class to the other.

Regarding license for health treatment, a greater number of women was observed compared to men.

Out of the six schools, only two had a computer with internet in the teachers' room. All of them had computer laboratory, library, mimeograph and an overhead projector. However, only five schools had a copying machine.

Heights of tables and chairs presented variation of more than $10 \mathrm{~cm}$ among them, interfering with posture of the teachers. Blackboard had varied heights, with $23 \mathrm{~cm}$ of difference. Windows presented varied measures, which facilitated or impaired natural light entry in the rooms.

The existence of inadequacies of the electric system in the classrooms was also observed, with concerned to switches, plugs, light bulbs and fans. Walls and ceilings were in need of care regarding cleanliness. 
Regarding illumination, intensity on the teachers' tables, $38.2 \%$ were inadequate.

Regarding environmental conditions (illumination, noise, humidity and temperature), they are shown as average with minimum and maximum values (Table 1).

Table 1

Distribution of environment conditions recorded during analysis of activities among state high school teachers in Viçosa - MG, 2009.

\begin{tabular}{lccccc}
\hline Variable & N & median & min. & max. & recommended \\
\hline Noise $(\mathrm{dB})$ & 219 & 88,7 & 50,4 & 105 & 65 \\
$\begin{array}{l}\text { Ilumination } \\
\begin{array}{l}\text { Lux) } \\
\text { Relative }\end{array}\end{array}$ & 155 & 218,0 & 33,0 & & 300 \\
$\begin{array}{l}\text { humidity } \\
\begin{array}{l}\text { Temperature } \\
\left({ }^{\circ} \mathrm{C}\right)\end{array}\end{array}$ & 154 & 26,9 & 20,9 & 32,1 & $20-23$ \\
\hline
\end{tabular}

$\mathrm{n}=$ frequency; Min. $=$ Minimum; Max. $=$ Maximum; $\mathrm{dB}=$ deci-

bels; $\% \mathrm{RH}=$ relative humidity percentage; ${ }^{\circ} \mathrm{C}=$ Celsius degrees

* NBR 10152, NBR 5413, NR 17, COUTO, 2002.

Room temperature, air relative humidity and noise level presented median and maximum values above the recommended. However, minimum value was within the range recommended for humidity.

There was a negative and statistically significant correlation $(\mathrm{p}<0.01)$ between temperature and air relative humidity, that is, the greater the temperature in the classroom, the lower air relative humidity and vice-versa.

Displacement of the teachers during work shift was $1.5 \mathrm{~km}$, measured by pedometer. For weight of material transported by teachers during classes and distance from school, it was found an average of $4.207 \mathrm{~kg}$, and the supplies transported were: diaries, books, tests, homework, notebooks, journal, chalk wooden case, bags and backpacks.

\subsection{Reports of body pains}

When presence of pain before working as a teacher was analyzed, there were more complaints of pain among women. The main pain sites related by men were: arm, vertebral column and hips. For women, it was highlighted as head, right shoulder, breast, vertebral column, legs and knees.

Absence of pain was similar in both sexes: $65.19 \%$ for male and $63.06 \%$ for female.

At the end of work day, it was noted that $15.2 \%$ of women presented with maximum level pain whereas only $8 \%$ of the men presented with maximum pain.

Still on pain complaints, when sites were separated into three big segments (back, upper limbs and lower limbs), there was a statistically significant association in the lower limbs $(\mathrm{p}<0.05)$, with a greater prevalence among women in relation to men.

When risk for musculoskeletal condition was evaluated, it was noted a greater tendency by women to develop some biomechanical disturbance due to their own structural condition in face of labor activity requirements.

\subsection{Burnout syndrome evaluation}

By analysis of the three dimensions of Burnout syndrome according to sex, it was found that men presented higher score for depersonalization whereas among women, the medium score was predominant (Table 2).

When it was observed per school, most of them presented prevalence for medium score in depersonalization.

Regarding emotional exhaustion, a statistically significant association with teachers with grad degree and work load greater than 18 classes per week was found. Thus, graduated teachers presented lower values for emotional exhaustion. On the contrary, those with high weekly hour load presented a higher score for emotional exhaustion.

There was a statistically significant association between depersonalization and both teacher sexes.

Concerning three dimensions of the Burnout syndrome and labor variables, correlation between noise and emotional exhaustion, pointed that the greater the noise in the classroom, the greater is the emotional exhaustion of the teachers.

Age and time of service presented negative and statically significant in relation to depersonalization, that is, the younger the age and working time, the greater depersonalization values.

A positive and statically significant correlation between emotional exhaustion and the number of week classes and depersonalization were observed, indicating that the more classes per week, the greater the emotional exhaustion. Personal fulfillment presented negative correlation, so, the lower the score for personal fulfillment, the greater the score for emotional exhaustion.

\section{Discussion}

The results found in this work reinforce the female participation in the teaching career; which is similar to other studies with samples of teachers [10-29-30-37]. 
Most of the teachers were married, what reinforces the situation of double or triple working hours, especially for women, in which household chores accumulates with work, creating domestic overload [2].

Working time is inferior to 5 years and age average is 40.4 years, indicating that most teachers started their professions after 30 years old and they have less teaching experience.

Concerning health, the regular physical activity of almost half of the sample should be highlighted. Benevides-Pereira, et al. (2002) [4], presented many techniques as a way of intervention in Burnout syndrome, emphasizing that sports help to "get rid of physical and mental tension, constituting a natural flush, which increases energy in the individual". Weight lifting, which is the physical activity practiced by most of the sample, is important for muscular mass maintenance, improving body composition, posture, and preventing pain which can be caused by muscular deficiencies. Studies show that weight lifting effectively contributes to reducing risk factors related to metabolic syndrome [14-19].

The big number of students in the classroom requires more voice intonation. According to Silvério et al. (2008) [34], increased effort in voice intonation causes wearing of vocal chords.

A greater number of work leaves by females, justifying public investment for preventing diseases and promoting health of the teachers were observed. Gasparini et al. (2005) [15] associate getting sick with characteristics of the schools and environment working conditions.

Regarding technological conditions of the work place, Rocha and Fernandes (2008) [31] emphasize the need to access technology; as globalization and technological progress influence work relationships, including school environment.

Height of the tables used by teachers varied, which may compromise adoption of proper and comfortable postures. According to Couto (2002) [13], the position seated and lightly inflected forward with the torso relaxed cause muscular pains due to fatigue of the back muscles, especially the great dorsal and trapezoid. Kroemer e Grandjean (2005) [21] recommended reading and writing work within the range of 74 to $78 \mathrm{~cm}$ for men and 70 to $74 \mathrm{~cm}$ for women.

Wiring reveals the need for periodical maintenance, reducing risks of electrical accidents and improving environment conditions.

Ceiling and walls were inadequate in color and cleanliness, what may interfere in the students learning and psycho-social behavior in the classroom. Such facts contribute to a greater emotional wear of the teachers due to restlessness of the students and difficulty to teach the class [21].

Table 2

Distribution of Burnout dimensions, according to ginger and school, among high school state teachers in Viçosa - MG, 2009.

\begin{tabular}{|c|c|c|c|c|c|c|c|c|c|}
\hline \multirow[t]{2}{*}{ Burnout dimensions } & \multicolumn{8}{|c|}{ Frequency and percentage $-\mathrm{n}(\%)$} & \multirow{3}{*}{$\begin{array}{l}\text { School } \\
6\end{array}$} \\
\hline & & & & School & Schoo & School & School & School & \\
\hline & General* & Men & Women & 1 & 2 & 3 & 4 & 5 & \\
\hline \multicolumn{10}{|l|}{ Emotional exhaustions } \\
\hline High (score $\geq 27$ ) & $40(47.1)$ & $16(55.2)$ & $24(42.9)$ & $8(72.7)$ & $6(30)$ & $3(37.5)$ & $7(77.8)$ & $7(46.7)$ & $9(40.9)$ \\
\hline Medium (score $19-26)$ & $28(32.9)$ & $5(17.2)$ & $23(41.1)$ & $2(18.2)$ & $8(40)$ & $4(50.0)$ & $1(11.1)$ & $4(26.7)$ & $9(40.9)$ \\
\hline Low (score < 19) & $17(20.0)$ & $8(27.6)$ & $9(16.1)$ & $1(7.7)$ & $6(30)$ & $1(12.5)$ & $1(11.1)$ & $4(26.7)$ & $4(18.2)$ \\
\hline \multicolumn{10}{|l|}{ Depersonalization } \\
\hline High $(\text { score } \geq 10)^{d}$ & $27(31.8)$ & $15(51.7)$ & $12(21.4)$ & $2(18.2)$ & $7(30,4)$ & $3(37.5)$ & $4(44.4)$ & $4(26.7)$ & $7(31.8)$ \\
\hline Medium (score 6-9) & $45(52.9)$ & $14(48.3)$ & $31(55.4)$ & $8(72.7)$ & $10(50)$ & $4(50.0)$ & $4(44.4)$ & $7(46.7)$ & $12(54.5)$ \\
\hline Low $(\text { score }<6)^{\mathrm{f}}$ & $13(15.3)$ & - & $13(23.2)$ & $1(9.1)$ & $3(15)$ & $1(12.5)$ & $1(11.1)$ & $4(26.7)$ & $3(13.6)$ \\
\hline \multicolumn{10}{|l|}{ Personal fulfiment ${ }^{\mathrm{c}}$} \\
\hline High $($ score $\leq 33)$ & $68(80.0)$ & $24(82.8)$ & $44(78.6)$ & $10(90.9)$ & $16(80)$ & $4(50)$ & $7(77.8)$ & $11(73.3)$ & $20(90.9)$ \\
\hline Medium (score $34-39$ ) & $16(18.8)$ & $5(17.2)$ & $11(19.6)$ & $1(9.1)$ & $4(20)$ & $3(37.5)$ & $2(22.2)$ & $4(22.2)$ & $2(9.1)$ \\
\hline Low $($ score $\geq 40)$ & $01(1.2)$ & - & $1(1.8)$ & - & - & $1(12.5)$ & - & - & - \\
\hline Total & $\begin{array}{l}85 \\
(100.0)\end{array}$ & $\begin{array}{l}29 \\
(100.0)\end{array}$ & $\begin{array}{l}56 \\
(100.0)\end{array}$ & $\begin{array}{l}11 \\
(100.0)\end{array}$ & $\begin{array}{l}20 \\
(100.0)\end{array}$ & $\begin{array}{l}8 \\
(100.0)\end{array}$ & $\begin{array}{l}9 \\
(100.0)\end{array}$ & $\begin{array}{l}15 \\
(100.0)\end{array}$ & $\begin{array}{l}22 \\
(100.0)\end{array}$ \\
\hline
\end{tabular}

* General $=$ Men and women together;

$\mathrm{a}=\mathrm{p}>0.05 ; \mathbf{b}=\mathbf{p}<\mathbf{0 . 0 5} ; \mathrm{c}=\mathrm{p}>0.05$;

Chi-square Test $\mathrm{dx}(\mathrm{e}+\mathrm{f})-\mathrm{p}<0.05$;

Fischer Test 
Considering that NR 15 determined 90 decibels as the sound exposition daily limit in a 4-hour shift, $41 \%$ of the sample was above this recommendation. Siqueira et al. (2008) [35] reinforced that noise above this recommendation impaired verbal communication, thus the teacher has to speak louder so that students pay attention to the lesson. According to Leucz et al. (2001) [22], exposition to intense noise after two hours, may result in annoyance, tension, headaches and fall of performance. According to Gonçalves et al. (2009) [17], it can culminate into hearing loss caused by noise (PAIR).

Illumination was above the recommended for writing and reading areas (300 LUX), which may cause progressive loss of vision over working years. Siqueira et al. (2008) [35] highlights that intellectual tasks need proper illumination. Besides, low illumination intensity can cause visual fatigue and fall on working yield.

The high values of temperature and humidity harm good development of class activities because thermal discomfort negatively influences behavior and metabolism of students and teachers [35]. According to Yang e Su (1997) [40], perception of thermal discomfort among men and women is different.

Analyzing work sites, manner of writing on the board, diversity of height of the professionals, position of the blackboard; all may cause musculoskeletal disturbances. This study revealed that most teachers reach more than $2.11 \mathrm{~m}$ to write on the blackboard but $25 \%$ do not reach $2.00 \mathrm{~m}$. such problem may be minimized by inserting a stage close to the board. As described by Bergmiller et al. (1999) [6] "the limits of the reach of most of the writing and the visual range and the lowest user of users sitting (in the case of frame-to-chalk) should be observed for determining the height of attachment of the components of the furniture", which is translated into English as "limits on writing reach of the taller and shorter user and visual scope of sitting users (blackboard in this case) must be observed for determining fixation of furniture."

Concerning work repetitiveness and organization, it was observed that teachers had limited time to perform their activities. There was only a short break when they moved to other classrooms and sometimes there were classes in a sequence, so they worked an hour load longer than four hours.

As for body pains, the report of maximum pain by teachers at the end of a work shift should be noted. When it was grouped into three segments, prevalence of pain among teachers of the sample was similar for upper and lower limbs, which was also found by Cardoso et al. (2009) [9]. The existence of pain suggests a rhythm or work load beyond the limit endured by the body. In the work by Cardoso et al. (2009) [9], an association was found between pain and occupational variables as, for example, working time superior to five years, great physical effort, another nonteaching paid activity, and high temperatures in the classroom. Besides, Barros et al. (2007) [3], called attention for the considerable physical load, which occurred due to the permanence of the teacher in orthostatic position for more than $90 \%$ of their activities in the classroom, in addition to different degrees of flexion of the cervical column.

Moreover, the constant walking of teachers in the classroom and around the school collaborated for pain in the lower limbs.

Tudor-Locke and Basset (2004) [38] presented the recommendation of 10,000 steps per day for an active person. In a study with American teachers, Bryant (2010) [8] found a result with 4,726 steps. The studied sample presents an average lower than the American population (2,281.9 steps), maybe due to the physical structure size of the schools referenced.

The weight of supplies transported by the teachers was observed in and the manner which they are transported, many times over their shoulders. Couto (2002) [13] determines that the Recommended Weight Limit (RWL) is $4 \mathrm{~kg}$, a value lower than the average found among teachers of the sample.

By analyzing the aspects related to Burnout syndrome, some important points were found. The teachers of this study present high indexes of emotional exhaustion and depersonalization, which are traits of this syndrome.

Symptoms as for example, nervousness, stress, mental tiredness, forgetfulness, insomnia, among others, reflects emotional exhaustion suffered by the teachers [24]. In this study, depersonalization was greater among men, which does not corroborate with the study of Silva and Carlotto (2003) [32], which presented greater indices of emotional exhaustion and depersonalization among women. According to Codo et al. (1999) [11], depersonalization is the key of Burnout syndrome whereas the other two dimensions may be associated with those syndromes.

Bock and Sarriera (2006) [7] highlighted the need of working social support, by using solidarity and feedback among colleagues; teaching attitudes and a good relationship with the students; and personal characteristics as authenticity and companionship. 
Speaking on strategies, it cannot be forgotten that coping, that is, manners of facing stressful situations can reflect in factors of protection of Burnout syndrome [16]. Mazon et al. (2008) [26], associating the dimensions of the syndrome with coping strategies, found that the greater the use of coping strategies, emotional support, focus on emotional and mental disconnexion, the lower the feeling of emotional exhaustion. Depersonalization is lower when coping is used more.

The greater number of classes also presented statistical association with emotional exhaustion, suggesting a raise in their salaries, so not to compromise their time at home with extension of working hours.

Analyzing association among depersonalization and gender of the teachers, the need of a better working condition planning by school managers and directors to avoid increase of this psychological and behavior alteration in female and male genders is emphasized.

Depersonalization associated with voice alterations will compromise the health of the teacher and quality of the performed work [20].

Association between noise and emotional exhaustion alerted for the necessity of a greater care regarding the noise in the classrooms, which may compromise the mental health of the teachers.

The result of the correlation between age and working time with depersonalization warns managers to pay attention of the professionals working for less time, avoiding the progress of this dimension which may interfere in emotional exhaustion and personal fulfillment. Tibúrcio and Moreno (2009) [37] did not find any significant correlation of age to depersonalization, which makes it different from our study, in which a positive correlation was found, of working time and depersonalization.

\section{Conclusions}

Evidences of Burnout syndrome are present in everyday life of the analyzed sample, and depersonalization is the key for other dimensions of Burnout.

Association between emotional exhaustion and graduation, weekly work load of classes, and depersonalization with gender reinforces the importance of teachers' mental healthcare.

Some measures should be taken to improve environmental factors in the classroom, in addition to an salary increase adjustment, to avoid the need of the teachers to work in many shifts to improve their salaries.

It was also observed that schools present an excessive number of students, impairing performance of the teachers in the classroom, not to mention the limited access of those professionals to technological resources in their work place. Another important finding is the occurrence of pain among the teachers, indicating the need of use of preventive and corrective actions of those injuries, as for example, a guide for adequate postures, warning for permitted weight during transportation of school supplies, and body stretching.

Therefore, it is extremely important to improve school environment by implanting public policies aimed at health improvement and risk prevention, emphasizing physical and mental health of the teachers. In addition, it is from massive investments in the public education that adequacy of human, physical and technological resources will become possible, providing improvements in the life and work quality of the school community and benefits to the society, in general.

\section{References}

[1] Alexandre AA, Mafra SCT. Determinação de variáveis antropométricas para auxiliar o processo de elaboração de projetos de situações de trabalho. Relatório final apresentado ao PIBIC/CNPq, 2004.

[2] Araújo TM, Godinho TM, Eduardo JFB, Almeida MM. Diferenciais do gênero no trabalho docente e repercussões sobre a saúde. Ciência \& Saúde Coletiva. Rio de Janeiro, v.11, n.4, p. 1117 - 1129, 2006. .[citado 2009 Mar 5] Disponível em URL: http://www.scielo.br/scielo.php

[3] Barros M.E, Zorzal DC, Almeida FS, Iglesias RZ, Abreu VGV. Saúde e trabalho docente: a escola como produtora de novas formas de vida. Revista Trabalho, Educação e Saúde. Rio de Janeiro, v. 5, n. 1, p. 103-123, 2007.[citado 2009 Nov 27] Disponível em URL: http://www.revista.epsjv.fiocruz.br//include/mostrarpdf

[4] Benevides-Pereira AMT. O processo de adoecer pelo trabalho. In: Benevides-Pereira AMT. (org.). Burnout: quando o trabalho ameaça o bem-estar do trabalhador. São Paulo: Casa do Psicólogo, 2002. 282 p.

[5] Benevides-Pereira AMT. O estado da arte do burnout no Brasil. Revista Eletrônica InterAção Psy. Maringá, ano 1, n. 1, p. 411, ago 2003. [citado 2009 Mar 14] Disponível em URL: http://www.saudeetrabalho.com.br/download_2/burnoutbenevides.pdf

[6] Bergmiller KH, Souza PL, Brandão MBA. Ensino fundamental: mobiliário escolar. Brasília: FUNDESCOLA MEC, 1999. $70 \mathrm{p}$.

[7] Bock VR, Sarriera JC. O grupo intervindo na Síndrome de Burnout. Psicologia Escolar e Educacional. v. 10, n. 1, jun. 2006. .[citado 2009 Mai 13] Disponível em URL: http://pepsic.homolog.bvsalud.org/scielo.php 
[8] Bryant C. Do you walk enough at work? American Council on Exercise.[citado 2010 Jan 15] Disponível em URL: www.nubella.com

[9] Cardoso JP, Ribeiro IQB, Araújo TM, Carvalho FM, Borges EJF. Prevalência de dor musculoesquelética em professores. Revista Brasileira de Epidemiologia. São Paulo, v. 12, n. 4, dez. 2009. .[citado 2009 Set 10] Disponível em URL: http://www.scielo.br/scielo.php

[10] Carlotto MS, Câmara SG. Análise fatorial do Maslach Burnout Inventory (MBI) em uma amostra de professores de instituições particulares. Psicologia em Estudo, Maringá, v.9, n.3, p. 499-505, set/dez, 2004. .[citado 2009 Set 10] Disponível em URL: http://www.scielo.br/scielo.php

[11] Codo W. Educação: Carinho e Trabalho. - Petrópolis, RJ: Vozes / Brasília: Confederação Nacional dos Trabalhadores em Educação: Universidade de Brasília. Laboratório de Psicologia do Trabalho, 1999. $432 \mathrm{p}$.

[12] Corlett EN, Manenica I. The effects and measurement of working postures. Applied Ergonomics, v. 11, n. 1, p. 7-16, 1980 .

[13] Couto HA. Ergonomia aplicada ao trabalho em 18 lições. Ilustrado por Ricardo Sá. - Belo Horizonte: Ergo, 2002. 201 p

[14] Dumith SC, Domingues MR, Gigante DP. Epidemiologia das atividades físicas praticadas no tempo de lazer por adultos no Sul do Brasil. Revista Brasileira de Epidemiologia. São Paulo, v. 12, n. 4, p. 646-658, 2009. .[citado 2010 Jan 10] Disponível em URL: http://www.scielo.br/scielo.php

[15] Gasparini SM, Barreto SM, Assunção AA. O professor, as condições de trabalho e os efeitos sobre sua saúde. Educação e Pesquisa. São Paulo, v. 31, n.2, p. 189-199, maio/ago. 2005. .[citado 2009 Mar 13] Disponível em URL: http://www.scielo.br/scielo.php

[16] Gil-Monte PR. Factorial validity of the Maslach Burnout Inventory (MBI-HSS) among spanish professionals. Revista de Saúde Pública. São Paulo, v.39, n.1, p. 1-8, 2005. .[citado 2009 Mai 15] Disponível em URL: http://www.scielo.br/scielo.php

[17] Gonçalves CGO, Lacerda ABM, Ribas A, Oliva FC, Almeida SB, Marques JM. Exposição ocupacional ao ruído em odontólogos do Paraná: percepções e efeitos auditivos. Revista de Odontologia da UNESP. Araraquara, v.38, n.4, p. 235-43, jul./ago. 2009. .[citado 2010 Jan 10] Disponível em URL: http://rou.hostcentral.com.br/PDF/

[18] Guérin F, Laville A, Daniellou F, Duraffourg J, Kerguelen A. Compreender o trabalho para transformá-lo - a prática da ergonomia. São Paulo - SP: Ed. Edgard Blucher Ltda, p. 200, 2001.

[19] Gutierres APM, Marins JCB. Os efeitos do treinamento de força sobre os fatores de risco da síndrome metabólica. Revista Brasileira de Epidemiologia. São Paulo, n. 11, v. 1, p. 147-58, 2008. .[citado 2010 Fev 13] Disponível em URL: http://www.scielo.br/scielo.php

[20] Jardim R, Barreto SM, Assunção AA. Condições de trabalho, qualidade de vida e disfonia entre docentes. Cadernos de Saúde Pública. Rio de Janeiro, v. 23, n. 10, p. 2439 - 2461, out / 2007. .[citado 2008 Out 10] Disponível em URL: http://www.scielo.br/scielo.php

[21] Kroemer KHE, Grandjeane E. Manual de ergonomia: adaptando o trabalho ao homem / K. H. E. Kroemer e E. Grandjean; trad. Lia B. de Macedo Guimarães. - 5. ed. - Porto Alegre: Bookman, 2005. 327 p.

[22] Leucz J. Ambiente de trabalho das salas de aula no ensino básico nas escolas de Curitiba. 2001. Mestrado [Dissertação] Florianópolis: Universidade Federal de Santa Catarina; 2001.

[23] Levy GCTM, Sobrinho FPN, Souza CAA. Síndrome de burnout em professores da rede pública. $15^{\circ}$ Congresso
Brasileiro de Ergonomia, ABERGO - Associação Brasileira de Ergonomia; Porto Seguro, BA, 2008.

[24] Lima MFEM, Lima-Filho DO. Work and health conditions of university professors. Ciência \& Cognição. Rio de Janeiro, v. 14, n.3, p.62-82, nov 2009. .[citado 2010 Mar 16] Disponível em URL: http://pepsic.bvsalud.org/scielo.php

[25] Maslach C, Jackson SE, Leiter MP. Maslach burnout inventory. (3rd ed.) Palo Alto, CA: Consulting Psychologists Press, p. $191-218,1997$.

[26] Mazon V, Carlotto MS, Câmara S. Síndrome de burnout e estratégias de enfrentamento em professores. Arquivos Brasileiros de Psicologia. Rio de Janeiro, v. 60, n. 1, abr 2008. .[citado 2009 Mai 9] Disponível em URL: http://www.psicologia.ufrj.br/abp

[27] Moreira DS, Magnago RF, Sakae TM, Magajewski FRL. Prevalência da síndrome de burnout em trabalhadores de enfermagem de um hospital de grande porte na Região Sul do Brasil. Cadernos de Saúde Pública, Rio de Janeiro, v. 25, n. 7, p. 1559-1568, 2009. .[citado 2010 Mai 13] Disponível em URL: http://www.scielo.br/pdf/csp/v25n7/14.pdf

[28] Panero J, Zelnik M. Las dimensiones humanas en los espacios interiores: estandares antropométricos. Barcelona: Gustavo Gili, 2002. 318 p.

[29] Penteado RZ, Pereira IMT. Qualidade de vida e saúde vocal de professores. Revista de Saúde Pública. São Paulo, v 41, n. 2, p. 236-43, 2007. .[citado 2009 Jun 11] Disponível em URL: http://www.scielo.br/scielo.php

[30] Reis EJFB, Carvalho FM, Araújo TM, Porto LA, Neto AMS Trabalho e distúrbios psíquicos em professores da rede municipal de Vitória da Conquista, Bahia, Brasil. Cadernos de Saúde Pública. Rio de Janeiro, n. 21, v. 5, p. 1480 - 1490, setout, 2005. .[citado 2009 Jun 8] Disponível em URL: http://www.scielo.br/scielo.php

[31] Rocha VM, Fernades MH. Qualidade de vida de professores do ensino fundamental: uma perspectiva para a promoção da saúde do trabalhador. Jornal Brasileiro de Psiquiatria. Rio de Janeiro, v. 57, n. 1, p. 23-27, 2008. .[citado 2009 Jun 8] Disponível em URL: http://www.scielo.br/scielo.php

[32] Silva GN, Carlotto MS. Síndrome de Burnout: um estudo com professores da rede pública. Psicologia Escolar Educacional. Campinas, v. 7, n. 2, dez. 2003. .[citado 2009 Jun 13] Disponível em URL: http://pepsic.homolog.bvsalud.org/scielo.php

[33] Silveira Filho ESD. Plataformas de força montadas em esteira ergométrica para análise de impactos na marcha humana. 1997 Mestrado [Dissertação]. Escola de Engenharia, Universidade Federal do Rio Grande do Sul, RS, 1997.

[34] Silvério KCA, Gonçalves CGO, Penteado RZ, Vieira TPG, Libardi A, Rossi D. Ações em saúde vocal: proposta de melhoria do perfil vocal de professores. Pró-fono - Revista de Atualização Científica. Barueri, v. 20, n. 3, p. 177 - 82, jul set, 2008. .[citado 2009 Jun 13] Disponível em URL: http://www.scielo.br/scielo.php

[35] Siqueira GR, Oliveira AB, Vieira RAG. Inadequação ergonômica e desconforto das salas de aula em instituição de ensino superior do Recife - PE. Revista Brasileira de Promoção de Saúde. Fortaleza, v. 21, n. 1, 19-28, 2008. .[citado 2009 Jun 5] Disponível em URL: http://www.unifor.br/images/pdfs/pdfs notitia/2146.pdf

[36] Tamayo MR. Relação entre a síndrome de burnout e os valores organizacionais no pessoal de enfermagem de dois hospitais públicos. 1997. Mestrado [Dissertação], Instituto de Psicologia, Universidade de Brasília, DF, 1997.

[37] Tibúrcio A, Moreno CRC. Síndrome de burnout em professores do ensino médio de escolas pertencentes à 
gerência regional de educação e inovação (GEREI) do município de Tubarão (SC). InterfacEHS - Revista de Gestão Integrada em Saúde do trabalho e Meio Ambiente. São Paulo, v. 4, n. 1, artigo 3, abr./ago. 2009. .[citado 2009 Nov 10] Disponível em

http://www.interfacehs.sp.senac.br/br/artigos.asp

[38] Tudor-Locke C, Basset DRJ. How Many Steps / Day Are Enough? Preliminary Pedometer Indices for Public Health. Sports Medicine, v. 34, n. 1, p. 1 - 8, 2004. .[citado 2009 Nov 10] Disponível em URL: http://www.health.utah.edu/peak/Health_Fitness/Tudor
[39] UIS - UNESCO. Institute for Statistics. Teachers and educational quality: monitoring global needs for 2015. Montreal; 2006. 215 p...[citado 2009 Nov 10] Disponível em URL: http://unesdoc.unesco.org/images/0014/001457/145754e.pdf

[40] Yang KH, Su CH. An Approach to building energy savings using the PMV Index. Rev Building and Environment. v. 32, n 1, p. 25-30, 1997. .[citado 2009 Nov 10] Disponível em URL: http://www.sciencedirect.com/science 